Article

\title{
Performance of Iron Plaque of Wetland Plants for Regulating Iron, Manganese, and Phosphorus from Agricultural Drainage Water
}

\author{
Xueying Jia ${ }^{1,2} \mathbb{D}^{\mathbb{D}}$, Marinus L. Otte ${ }^{3}$, Ying Liu ${ }^{1,2}$, Lei Qin ${ }^{1,2}$, Xue Tian ${ }^{1}$, Xianguo Lu ${ }^{1,4}$, \\ Ming Jiang ${ }^{1,4, *}$ and Yuanchun Zou ${ }^{1,4, *}$ (iD \\ 1 Key Laboratory of Wetland Ecology and Environment, Northeast Institute of Geography and Agroecology, \\ Chinese Academy of Sciences, Changchun 130102, China; jiaxueying13@mails.ucas.ac.cn (X.J.); \\ liuying2011@163.com (Y.L.); qinlei@iga.ac.cn (L.Q.); tianxue2324@163.com (X.T.); luxg@neigae.ac.cn (X.L.) \\ 2 University of Chinese Academy of Sciences, Beijing 100049, China \\ 3 Wet Ecosystem Research Group, Department of Biological Sciences, North Dakota State University, \\ Fargo, ND 58105-6050, USA; marinus.otte@ndsu.edu \\ 4 Jilin Provincical Joint Key Laboratory of Changbai Mountain Wetland and Ecology, \\ Changchun 130102, China \\ * Correspondence: jiangm@iga.ac.cn (M.J.); zouyc@iga.ac.cn (Y.Z.); Tel.: +86-8554-2207 (M.J.)
}

Received: 30 November 2017; Accepted: 5 January 2018; Published: 8 January 2018

\begin{abstract}
Agricultural drainage water continues to impact watersheds and their receiving water bodies. One approach to mitigate this problem is to use surrounding natural wetlands. Our objectives were to determine the effect of iron (Fe)-rich groundwater on phosphorus $(\mathrm{P})$ removal and nutrient absorption by the utilization of the iron plaque on the root surface of Glyceria spiculosa (Fr. Schmidt.) Rosh. The experiment was comprised of two main factors with three regimes: $\mathrm{Fe}^{2+}\left(0,1,20,100,500 \mathrm{mg} \cdot \mathrm{L}^{-1}\right)$ and $\mathrm{P}\left(0.01,0.1,0.5 \mathrm{mg} \cdot \mathrm{L}^{-1}\right)$. The deposition and structure of iron plaque was examined through a scanning electron microscope and energy-dispersive $\mathrm{X}$-ray analyzer. Iron could, however, also impose toxic effects on the biota. We therefore provide the scanning electron microscopy (SEM) on iron plaques, showing the essential elements were iron ( $\mathrm{Fe}$ ), oxygen $(\mathrm{O})$, aluminum $(\mathrm{Al})$, manganese $(\mathrm{Mn}), \mathrm{P}$, and sulphur (S). Results showed that (1) Iron plaque increased with increasing $\mathrm{Fe}^{2+}$ supply, and P-deficiency promoted its formation; (2) Depending on the amount of iron plaque on roots, nutrient uptake was enhanced at low levels, but at higher levels, it inhibited element accumulation and translocation; (3) The absorption of manganese was particularly affected by iron plague, which also enhanced phosphorus uptake until the external iron concentration exceeded $100 \mathrm{mg} \cdot \mathrm{L}^{-1}$. Therefore, the presence of iron plaque on the root surface would increase the uptake of $\mathrm{P}$, which depends on the concentration of iron-rich groundwater.
\end{abstract}

Keywords: wetlands; agricultural drainage water; iron plague; phosphorus; manganese

\section{Introduction}

Agricultural activities are vital to the crop production and economy of terrestrial ecosystems; meanwhile, its practice continues to place environmental pressures on nearby lake and wetland ecosystems [1]. Agricultural drainage water originating from groundwater contains large amount of farm nutrients and high concentration of iron (Fe), which posing an environmental hazard to the surrounding ecosystems. In recent years, the area of rice cultivation has been increased to 4,000,000 ha of land in Heilongjiang Province, China. Such a large-scale agricultural production would inevitably bring great impacts on the surrounding ecosystems, especially for the sustainability and water security of the lake and wetlands. 
Wetlands play important roles in nutrient recycling, increasing dissolved $\mathrm{O}_{2}$ in the rhizosphere, recharging of aquifers, stabilization of water currents, improvement of water quality, and remediation of wastewater (including removal of excess iron, manganese, and other metals) [2-5]. Wetland plants have the capacity to improve water quality through mobilization and absorption of nutrients and contaminants [6]. $\mathrm{O}_{2}$ diffuses from the roots to their surroundings and oxidizes $\mathrm{Fe}^{2+}$ in the rhizosphere into oxyhydroxide iron (Fe plaque) on the root surface of plants [7]. Iron plaque on roots absorbs metals onto its large surface area and co-precipitates with nutrients, such as P. Root activities influence plaque formation by releasing $\mathrm{O}_{2}$ and exudates, and influencing the rates of enzyme and radial oxygen loss (ROL). Iron plaque formation occurs commonly on the surface of roots of wetland species, including Typha latifolia L., Oryza sativa L., and Phragmites communis Trin. [8].

Metal and nutrient enrichment and deposition in iron plaque are known to occur, but the effects of iron plaque on uptake and translocation of elements are still unclear [9-11]. Some studies reported that the formation of Fe plaque prevents the excessive uptake of Fe, Mn, Zn [12,13], and phosphorus (P) [14]. On the other hand, iron plaque acts as a buffer for $\mathrm{P}, \mathrm{Zn}, \mathrm{Cu}, \mathrm{Se}$, and As. While the plants may be lack nutrients, they are also at risk of metal toxicity $[15,16]$. The effects of Fe plaque on mineral nutrients and other elements may be related to the amount of deposition on the root. It has been reported that Fe plaque enhanced $\mathrm{Zn}$ and $\mathrm{P}$ uptake, and could be considered as a nutrient reservoir, but may also act as a barrier when excess Fe plaque forms on the root surface $[7,17]$. The presence of $P$ is important in energy metabolism, the biosynthesis of nucleic acids, photosynthesis, and enzyme regulation [18], and also plays an important role in biogeochemical cycling with Fe and Mn $[19,20]$. The studies have demonstrated that P-deficiency may enhance the formation of iron plaque on the roots of plants [21,22]. At the same time, iron plaque on the root surface may affect the uptake and translocation of $\mathrm{P}, \mathrm{Mn}, \mathrm{Zn}$, $\mathrm{Cu}$, As, and $\mathrm{Cd}$. Using reactive materials to immobilize $\mathrm{P}$ in soils or manure is considered a new way of managing P eutrophication [23].

In order to adapt to long-term iron-rich environmental changes, wetland plants have different growth strategies in different environments. Higher plants have developed two divided strategies to acquire slightly soluble iron from the rhizosphere: the chelation strategy of graminaceous plants and the reduction strategy of nongraminaceous plants [9]. The "exclusion" strategy is supported by studies, which showed that some species exclude phytotoxic metals rather than absorbing them. The presence of iron plaque on the root surface is another strategy, which is an adaptation to flooding. With the iron plaque strategy, the absorption and translocation of a large number of elements will be affected.

The aim of this study was to determine the effects of iron toxicity on plants when they are grown in the iron-rich groundwater and agricultural drainage water recharge marsh, such as the Xiaoxingkai Lake wetland in the south of the Sanjiang Plain, China. Xiaoxingkai Lake is a Chinese National Nature Reserve and a boundary lake between China and Russia. The experimental wetland plant was Glyceria spiculosa (G. spiculosa), a typical dominant but sensitive species with developed aerenchyma in the roots. Therefore, the variation of G. spiculosa has a certain indicative function on the change of the surrounding habitat. In the present investigation, our main objectives were to study the effects of: (a) $\mathrm{P}$ and Fe concentrations on the formation of iron plaque on root surfaces; (b) iron plaque on the uptake and translocation of $\mathrm{Fe}, \mathrm{Mn}$, and $\mathrm{P}$; and (c) iron-rich groundwater as a reactive resource to manage $P$ eutrophication water caused by the agricultural drainage water.

\section{Materials and Methods}

\subsection{Greenhouse Experiment}

To investigate the influence of various $\mathrm{Fe}^{2+}$ and $\mathrm{P}$ concentrations levels on the formation of iron plaque and its function on elements uptake and translocation, an experiment was performed with G. spiculosa. The experiment was carried out in a greenhouse at Northeast Institute of Geography and Agroecology, Chinese Academy of Sciences ( $43^{\circ} 59^{\prime} 53^{\prime \prime} \mathrm{N}$ and $125^{\circ} 23^{\prime} 48^{\prime \prime}$ E) during July to 
September, 2016. Average air temperatures during the day (7:00-19:00) were $25-28{ }^{\circ} \mathrm{C}$, and during the night they were (19:00-7:00) $15-20^{\circ} \mathrm{C}$.

Before beginning the experiment, tillers training were pre-cultured for two weeks in the greenhouse. The plants were tiled on the plastic vessels $(100 \times 60 \times 5 \mathrm{~cm})$ containing 10 L half-strength Hoagland nutrient solution (Hoagland and Arnon 1950), and the solution was renewed every seven days. Tillers of uniform size $(15-18 \mathrm{~cm})$ were selected on the rhizomes of the G. spiculosa, cleaned with deionized water, and transplanted to plastic pots (12 cm diameter, $15 \mathrm{~cm}$ height) into quartz sand and half-strength Hoagland nutrient solution for one week. The Hoagland solution was composed of $0.5 \mathrm{mM} \mathrm{NH}_{4} \mathrm{H}_{2} \mathrm{PO}_{4}, 2 \mathrm{mM} \mathrm{Ca}\left(\mathrm{NO}_{3}\right)_{2} \cdot 4 \mathrm{H}_{2} \mathrm{O}, 3 \mathrm{mM} \mathrm{KNO}_{3}, 1 \mathrm{mM} \mathrm{MgSO}_{4} \cdot 7 \mathrm{H}_{2} \mathrm{O}, 4.57 \mu \mathrm{M} \mathrm{MnCl}_{2} \cdot 4 \mathrm{H}_{2} \mathrm{O}$, $23.13 \mu \mathrm{M} \mathrm{H}_{3} \mathrm{BO}_{3}, 0.382 \mu \mathrm{M} \mathrm{ZnSO}_{4} \cdot 7 \mathrm{H}_{2} \mathrm{O}, 0.16 \mu \mathrm{M} \mathrm{CuSO}_{4} \cdot 5 \mathrm{H}_{2} \mathrm{O}$, and $0.0695 \mu \mathrm{MMoO}_{3}$.

\subsection{Experiment Design}

The experiment was comprised of two main factors with three regimes: $\mathrm{Fe}^{2+}(0,1,20,100$, $\left.500 \mathrm{mg} \cdot \mathrm{L}^{-1}\right)$ and $\mathrm{P}\left(0.01,0.1,0.5 \mathrm{mg} \cdot \mathrm{L}^{-1}\right)$ (Table 1$)$. The first regime lasted three weeks, with ferrous sulfate in the half-strength Hoagland nutrient solution, which was designed to examine the influence of different $\mathrm{Fe}^{2+}$ concentrations and the resistance threshold of wetland plants to excessive $\mathrm{Fe}^{2+}$ treatment. The second regime lasted one week, with ferrous sulfate addition, but did not contain phosphorus in the solution, as it intended to flush out residual $\mathrm{PO}_{4}-\mathrm{P}$ and prompt the iron plaque formation on the roots. The third regime lasted two weeks with ammonium dihydrogen phosphate addition, to determine the influence of iron plague in the asorption and translocation of $\mathrm{Fe}, \mathrm{Mn}$, and P. Each treatment consisted of five replications in a large rectangular trough $(67 \times 26 \times 22 \mathrm{~cm})$, with a total of 75 pots. The pots were waterlogged $(2-3 \mathrm{~cm})$ with the testing solution, and the bottom of each pot had five small holes. Each of the pots were wrapped with a black plastic bag. The nutrient solution was renewed every seven days, and the $\mathrm{pH}$ was adjusted to $5.5 \mathrm{using} 0.2 \mathrm{~mol} \cdot \mathrm{L}^{-1} \mathrm{NaOH}$ or $\mathrm{HCl}$ every two days.

\subsection{Scanning Electron Microscopy (SEM) and Energy Dispersive X-Ray Spectrometry (EDS)}

Root material was washed with tap water, then rinsed three times in deionized water. For the scanning electron microscopy analysis, $1 \mathrm{~cm}$ long lateral fresh root samples of G. spiculosa were prepared and fixed in formyl acetic alcohol (FAA). Samples were dehydrated in ethyl series and dried using liquid $\mathrm{CO}_{2}$ (CPD 030 model, Bal-Tec Co., Balzers, Liechtenstein). The morphology of roots was observed using a scanning electron microscopy (SS-550, Shimadzu, Tokyo, Japan).

\subsection{Chemical Analysis}

At the end of the experiment, the plants were harvested and separated into roots, stems, and leaves, and washed with deionised water three times. Fresh root samples were weighted $1 \mathrm{~g}$ and then soaked by dithionite-citrate-bicarbonate (DCB) [24]. The DCB solution consisted of $40 \mathrm{~mL}$ of $0.3 \mathrm{M}$ sodium dithionite and $5 \mathrm{~mL}$ of $1 \mathrm{M}$ sodium citrate with $3.0 \mathrm{~g}$ sodium dithionite. The roots in the solution were shaken for $3 \mathrm{~h}$ for a complete extraction. The extrated roots were dried at $60{ }^{\circ} \mathrm{C}$ to constant weight. Fe concentrations in DCB were determined by atomic absorption (Optima 2000DV, Perkin Elmer, Waltham, MA, USA).

The other plant biomass comparments were dried at $55{ }^{\circ} \mathrm{C}$ for $72 \mathrm{~h}$, used to measure iron, manganese, and phosphrous with perchloric $\left(\mathrm{HClO}_{4}\right)$ acids and nitric $\left(\mathrm{HNO}_{3}\right)(1: 5, v / v)$. The concentrations of iron and manganese in plant tissues were assayed by atomic absorption spectrometry (Optima 2000DV, Perkin Elmer, Waltham, MA, USA), and phophrous was determined with Molybdenum antimony colorimetric method by Automatic chemistry analyzer (Smartchem 300, Advanced Monolithic Systems, Graz, Italy). 
Table 1. Experimental treatment for a fully factorial design with three regimes and two main factors: $\mathrm{Fe}^{2+}\left(0,1,20,100,500 \mathrm{mg} \cdot \mathrm{L}^{-1} \mathrm{Fe}\right)$ and $\mathrm{P}\left(0.01,0.1,0.5 \mathrm{mg} \cdot \mathrm{L}^{-1} \mathrm{P}\right)$.

\begin{tabular}{|c|c|c|c|c|c|c|c|c|c|c|c|c|c|c|c|}
\hline \multirow{2}{*}{$\begin{array}{l}\text { Time } \\
\text { (Weeks) }\end{array}$} & \multicolumn{15}{|c|}{ Treatments } \\
\hline & \multicolumn{3}{|c|}{ Fe 0} & \multicolumn{3}{|c|}{ Fe 1} & \multicolumn{3}{|c|}{ Fe 20} & \multicolumn{3}{|c|}{ Fe 100} & \multicolumn{3}{|c|}{ Fe 500} \\
\hline 1 & \multicolumn{3}{|c|}{$\mathrm{Fe} 0+H$} & \multicolumn{3}{|c|}{$\mathrm{Fe} 1+H$} & \multicolumn{3}{|c|}{$\mathrm{Fe} 20+H$} & \multicolumn{3}{|c|}{$\mathrm{Fe} 100+H$} & \multicolumn{3}{|c|}{$\mathrm{Fe} 500+H$} \\
\hline 2 & \multirow{2}{*}{\multicolumn{3}{|c|}{$\begin{array}{l}\text { Fe } 0+H \\
\text { Fe } 0+H\end{array}$}} & \multicolumn{3}{|c|}{$\mathrm{Fe} 1+H$} & \multicolumn{3}{|c|}{$\mathrm{Fe} 20+H$} & \multicolumn{3}{|c|}{$\mathrm{Fe} 100+H$} & \multicolumn{3}{|c|}{ Fe $500+H$} \\
\hline 3 & & & & \multirow{2}{*}{\multicolumn{3}{|c|}{$\begin{array}{c}\text { Fe } 1+H \\
\text { Fe } 1+H(-P)\end{array}$}} & \multirow{2}{*}{\multicolumn{3}{|c|}{$\begin{array}{c}\text { Fe } 20+H \\
\text { Fe } 20+H(-P)\end{array}$}} & \multirow{2}{*}{\multicolumn{3}{|c|}{$\begin{array}{c}\text { Fe } 100+H \\
\text { Fe } 100+H(-P)\end{array}$}} & \multirow{2}{*}{\multicolumn{3}{|c|}{$\begin{array}{c}\text { Fe } 500+H \\
\text { Fe } 500+H(-P)\end{array}$}} \\
\hline 4 & \multicolumn{3}{|c|}{$\mathrm{Fe} 0+H(-P)$} & & & & & & & & & & & & \\
\hline 5 & $+0.01 \mathrm{PH}$ & $+0.1 \mathrm{PH}$ & $+0.5 \mathrm{PH}$ & $+0.01 \mathrm{PH}$ & $+0.1 \mathrm{PH}$ & $+0.5 \mathrm{PH}$ & $+0.01 \mathrm{PH}$ & $+0.1 \mathrm{PH}$ & $+0.5 \mathrm{PH}$ & $+0.01 \mathrm{PH}$ & $+0.1 \mathrm{PH}$ & $+0.5 \mathrm{PH}$ & $+0.01 \mathrm{PH}$ & $+0.1 \mathrm{PH}$ & $+0.5 \mathrm{PH}$ \\
\hline 6 & $+0.01 \mathrm{PH}$ & $+0.1 \mathrm{PH}$ & $+0.5 \mathrm{PH}$ & $+0.01 \mathrm{PH}$ & $+0.1 \mathrm{PH}$ & $+0.5 \mathrm{PH}$ & $+0.01 \mathrm{PH}$ & $+0.1 \mathrm{PH}$ & $+0.5 \mathrm{PH}$ & $+0.01 \mathrm{PH}$ & $+0.1 \mathrm{PH}$ & $+0.5 \mathrm{PH}$ & $+0.01 \mathrm{PH}$ & $+0.1 \mathrm{PH}$ & $+0.5 \mathrm{PH}$ \\
\hline
\end{tabular}

Notes: $H=$ half-strength Hoagland nutrient solution; $H(-P)=$ not contain phosphorus in $H ; 0.01 \mathrm{PH}=0.01 \mathrm{mg} \cdot \mathrm{L}^{-1}$ phosphorus in the $H(-P) ; 0.1 \mathrm{PH}=0.1 \mathrm{mg} \cdot \mathrm{L}^{-1}$ phosphorus in the $H(-P) ; 0.5 \mathrm{PH}=0.5 \mathrm{mg} \cdot \mathrm{L}^{-1}$ phosphorus in the $H(-P)$. 


\subsection{Data Analysis and Statistical Analysis}

$\mathrm{Fe}(\mathrm{Mn}, \mathrm{P})$ content $(\mathrm{g})=\mathrm{Fe}(\mathrm{Mn}, \mathrm{P})$ concentration $\times$ dry matter.

Concentration of Fe plaque $(\mu \mathrm{g} / \mathrm{g})=$ Fe plaque content/roots dry matter.

Translocation of $\mathrm{Fe}, \mathrm{P}, \mathrm{Mn}$ from roots to the stems and leaves, and element aquisition efficiency (FeAE, MnAE, PAE) were calculated as follows:

Translocation of Fe $(\mathrm{Mn}, \mathrm{P})$ in stems $(\%)=\mathrm{Fe}(\mathrm{Mn}, \mathrm{P})$ content in stems $/$ total Fe $(\mathrm{Mn}, \mathrm{P})$ content in plants $\times 100$.

Translocation of Fe $(\mathrm{Mn}, \mathrm{P})$ in leaves $(\%)=\mathrm{Fe}(\mathrm{Mn}, \mathrm{P})$ content in leaves/total Fe $(\mathrm{Mn}, \mathrm{P})$ content in plants $\times 100$.

Fe acquisition efficiency $\left(\mathrm{FeAE}, \mathrm{mg} \cdot \mathrm{g}^{-1}\right)=$ total Fe content in plants/the root dry matter.

$\mathrm{Mn}$ acquisition efficiency $\left(\mathrm{Mn} \mathrm{AE}, \mathrm{mg}^{-\mathrm{g}^{-1}}\right)=$ total Mn content in plants/the root dry matter.

$\mathrm{P}$ acquisition efficiency (PAE, $\mathrm{mg} \cdot \mathrm{g}^{-1}$ ) $=$ total $\mathrm{P}$ content in plants / the root dry matter.

Statistical analyses were performed with SPSS Statistics 20.0. Two-way ANOVA tests were performed according to any interactions of the Fe and P treatments. The Kolmogorov-Smirnov test was used to test for normality. The data of iron plaque were square root transformed before parametric analysis. The Levene's test was performed to test for the homogeneity of variances. Significant differences between treatments in means were compared using Tukeys's with significance set at $p \leq 0.05$.

\section{Result}

\subsection{Iron Plaque Formation on the Root}

DCB-extractable Fe concentrations from the roots of G. spiculosa varied from 2.1-233 $\mu \mathrm{g} \cdot \mathrm{g}^{-1}$, with the highest value recorded at the $\mathrm{Fe} 500 / \mathrm{P} 0.01$ treatment, and the lowest value at Fe $0 / \mathrm{P} 0.5$ treatment (Figure 1). The iron plaque was visually present on the root surface of Fe 20-Fe 500 . There was a sharp increase of iron plaque at the concentration of $\mathrm{Fe} 500$, which was about seven times higher than that of Fe 100. In both Fe 0 and Fe 1 treatments, there were no statistically significant differences in the formation of iron plaque. With the increase of $\mathrm{Fe}^{2+}$ applied, the amount of iron plaque with P 0.01 were higher than P 0.1 and P 0.5 for $20-500 \mathrm{mg} \cdot \mathrm{L}^{-1}$ Fe treatments.

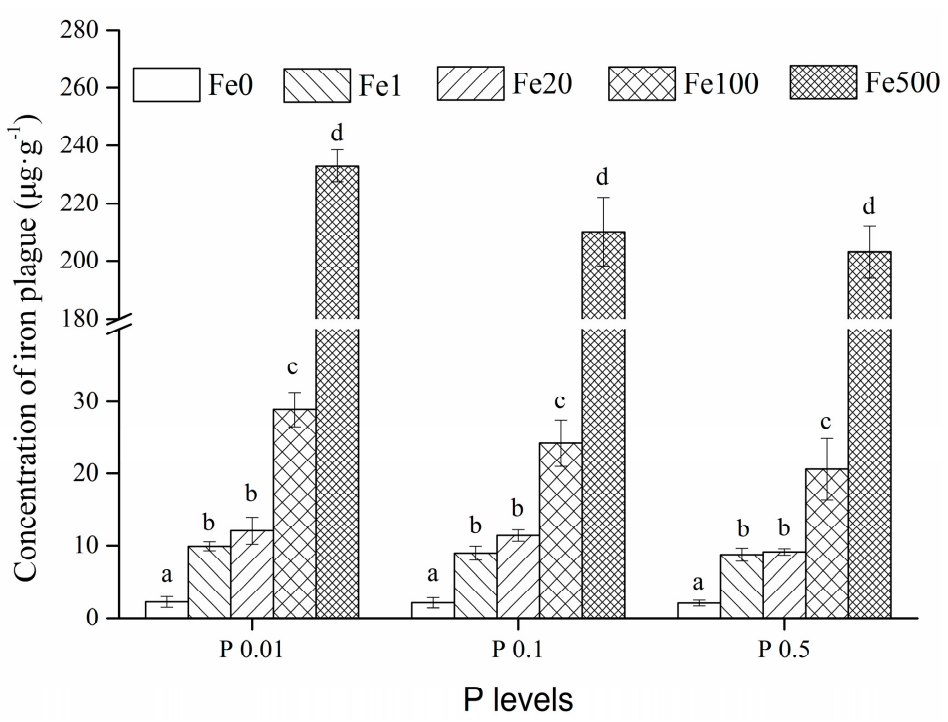

Figure 1. The amount of iron plaque on roots surface of $G$. spiculosa grown hydroponically with varying $\mathrm{Fe}^{2+}$ concentrations and P levels. Values (mean $\pm \mathrm{SE}, n=3$ ) followed by different letters designate significant differences $(p<0.05)$ between $\mathrm{Fe}^{2+}$ concentrations for a given $\mathrm{P}$ level $(\mathrm{a}, \mathrm{b}, \mathrm{c}, \mathrm{d})$. The data were square root transformed before statistical analysis. 


\subsection{Dry Matter Accumulation}

Dry matter of plants were significantly affected by Fe and P concentrations (Table 2). In plants exposed to Fe 20 and above, the dry matter of roots were decreased considerably, whereas the dry matter of stems and leaves showed similar response patterns, peaking at Fe 20 and subsequently decreasing with increasing Fe application, with stems ranging from $0.47 \mathrm{~g}$ (Fe 500/P 0.1) to $1.10 \mathrm{~g}$ (Fe 20/P 0.01) and leaves ranging from $0.15 \mathrm{~g}$ (Fe 500/P 0.1) to $0.93 \mathrm{~g}$ (Fe 20/P 0.01). The highest plant biomass at the three P levels was mostly observed at P 0.01 and a few appeared at P 0.5 treatment. The results showed that plants have different biomass distribution patterns for organs with varying Fe and P concentrations.

Table 2. Dry matter of G. spiculosa exposed to different concentrations of Fe and P (mean \pm SE, $n=5$ ), and the analysis of variance (two-way ANOVA) on dry matter.

\begin{tabular}{|c|c|c|c|c|c|c|c|}
\hline \multicolumn{8}{|c|}{ Dry Matter (g) } \\
\hline $\mathrm{Fe} 0 / \mathrm{P} 0.01$ & $0.51 \pm 0.03 b$ & $0.59 \pm 0.02 \mathrm{ab}$ & $0.52 \pm 0.05 b c$ & $\mathrm{Fe} 1 / \mathrm{P} 0.01$ & $0.54 \pm 0.02 b$ & $0.83 \pm 0.04 c$ & $0.69 \pm 0.03 c$ \\
\hline $\mathrm{Fe} 0 / \mathrm{P} 0.5$ & $0.44 \pm 0.03 b c$ & $0.79 \pm 0.06 \mathrm{~b}$ & $0.56 \pm 0.02 b c$ & $\mathrm{Fe} 1 / \mathrm{P} 0.5$ & $0.33 \pm 0.04 b c$ & $0.86 \pm 0.05 b$ & $0.67 \pm 0.05 \mathrm{~cd}$ \\
\hline $\mathrm{Fe} 20 / \mathrm{P} 0.01$ & $0.46 \pm 0.03 b$ & $1.10 \pm 0.10 \mathrm{~d}$ & $0.93 \pm 0.08 \mathrm{~d}$ & $\mathrm{Fe} 100 / \mathrm{P} 0.01$ & $0.43 \pm 0.04 b$ & $0.79 \pm 0.08 \mathrm{bc}$ & $0.49 \pm 0.02 b$ \\
\hline $\mathrm{Fe} 20 / \mathrm{P} 0.1$ & $0.34 \pm 0.03 b$ & $0.86 \pm 0.07 c$ & $0.80 \pm 0.09 c$ & $\mathrm{Fe} 100 / \mathrm{P} 0.1$ & $0.28 \pm 0.04 b$ & $0.54 \pm 0.04 \mathrm{~b}$ & $0.41 \pm 0.05 b$ \\
\hline $\mathrm{Fe} 500 / \mathrm{P} 0.1$ & $0.09 \pm 0.01 \mathrm{a}$ & $0.47 \pm 0.03 a$ & $0.15 \pm 0.02 \mathrm{a}$ & $\mathrm{Fe}$ & $<0.001$ & $<0.001$ & $<0.001$ \\
\hline \multirow[t]{2}{*}{$\mathrm{Fe} 500 / \mathrm{P} 0.5$} & $0.19 \pm 0.02 \mathrm{a}$ & $0.50 \pm 0.06 \mathrm{a}$ & $0.22 \pm 0.03 \mathrm{a}$ & $\mathrm{P}$ & $<0.01$ & $<0.05$ & NS \\
\hline & & & & $\mathrm{Fe} \times \mathrm{P}$ & NS & $<0.01$ & NS \\
\hline
\end{tabular}

Note: Different letters designate significant differences $(p<0.05)$ between $\mathrm{Fe}^{2+}$ concentrations for a given $\mathrm{P}$ level $(a, b, c, d)$.

\subsection{SEM and EDS Analysis}

The morphological analysis of roots by SEM showed that iron plaque clearly visible as an orange-brown deposition on the root surfaces. Figure 2A showed the root surface of Fe 0 treatment, which was the lowest deposition with plaque. The coating was extensively distributed across the root surface and consistently increased with increasing $\mathrm{Fe}^{2+}$ (Figure 2B-E,b-e). Microorganisms were also observed on the root surfaces of G. spiculosa, such as Figure 2a,b.

To confirm these visual observations, further examination was conducted by Energy Dispersive $X$-ray Spectrometry (EDS) scanning. Different colors were added to the image representing various elements. Figure 3 shows bright particles deposited on the root surfaces of Fe 500/P 0.1. In this image, Fe is represented by red, $\mathrm{P}$ by green, Mn by purple, and $\mathrm{S}$ by blue. The element of Fe was more dense than $\mathrm{P}$ and $\mathrm{Mn}$.

\subsection{Uptake and Accumulation of Fe, $\mathrm{Mn}, P$}

For each tissue type, the patterns of Fe content were similar for the same Fe and P treatments (Figure 4). Increasing Fe concentrations significantly increased the Fe content of roots, stems, and leaves. The highest Fe contents for Fe 0-Fe 20 treatments were found in the roots with 1.10-3.97 mg (stems with $0.33-2.11 \mathrm{mg}$ and leaves with $0.10-0.46 \mathrm{mg}$ ); however, Fe 100 and Fe 500 were found in the stems with 9.63-27.87 mg (roots with 5.92-15.22 $\mathrm{mg}$ and leaves with 1.13-4.95 mg). At the three P levels in a given Fe concentration, the total Fe content of $\mathrm{P} 0.01$ in $\mathrm{Fe} 0-\mathrm{Fe} 20$ treatment was higher than the other P levels, and higher in the Fe 100/P 0.5 and Fe 500/P 0.1 treatments. 

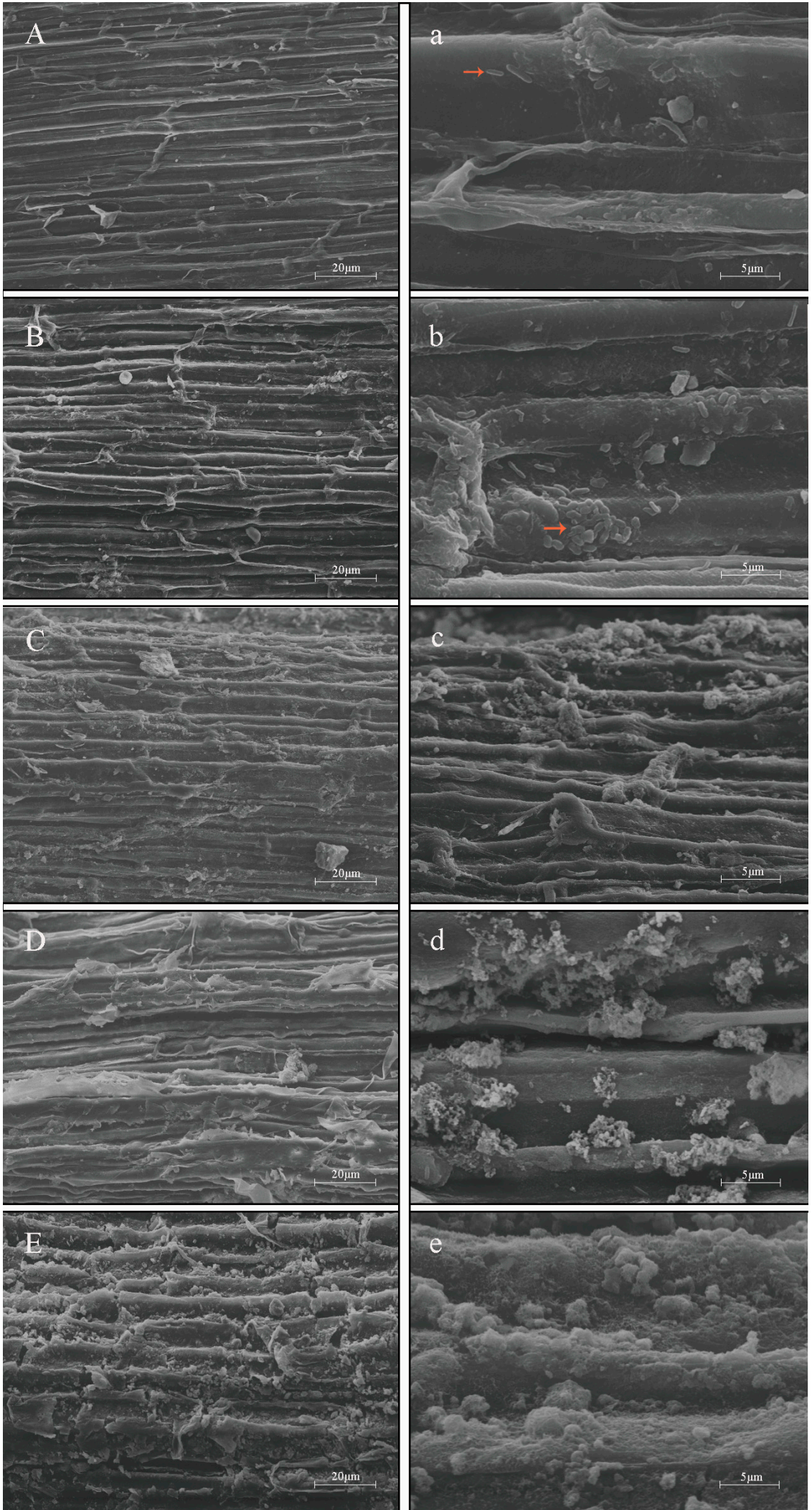

Figure 2. Different amounts of iron plaque formed on the roots of G. spiculosa observed by Scanning Electron Microscopy (SEM), accuracy of $20 \mu \mathrm{m}$ : (A-E), accuracy of $40 \mu \mathrm{m}$ : (a-e). Five treatments were represented: Fe 0/P 0.1, Fe 1/P 0.1, Fe 20/P 0.1, Fe 100/P 0.1, Fe 500/P 0.1. Red arrows indicated microorganisms exsiting on the roots surface. 


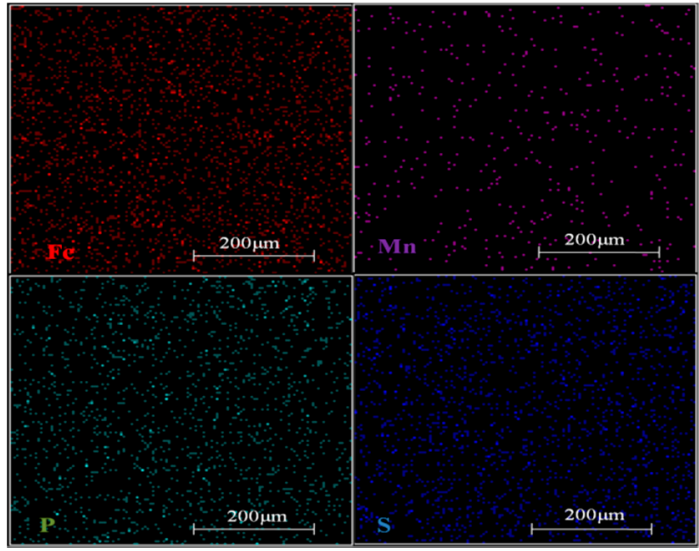

(a)

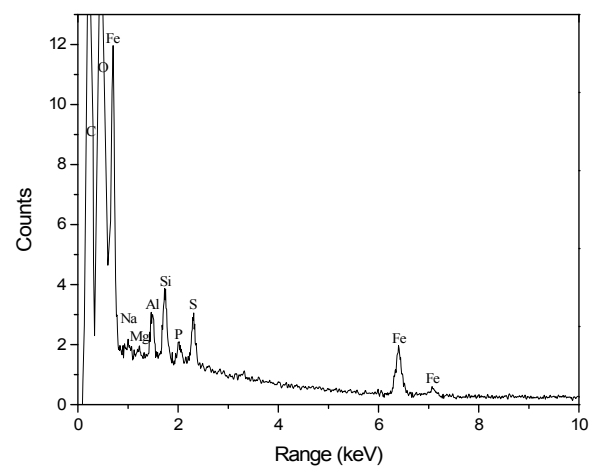

(b)

Figure 3. Energy Dispersive X-ray Spectrometry (EDS) on the root surface of G. spiculosa: distribution of $\mathrm{Fe}, \mathrm{Mn}, \mathrm{P}$, and $\mathrm{S}(\mathbf{a})$, and a quantitative determination of elements composition (b).
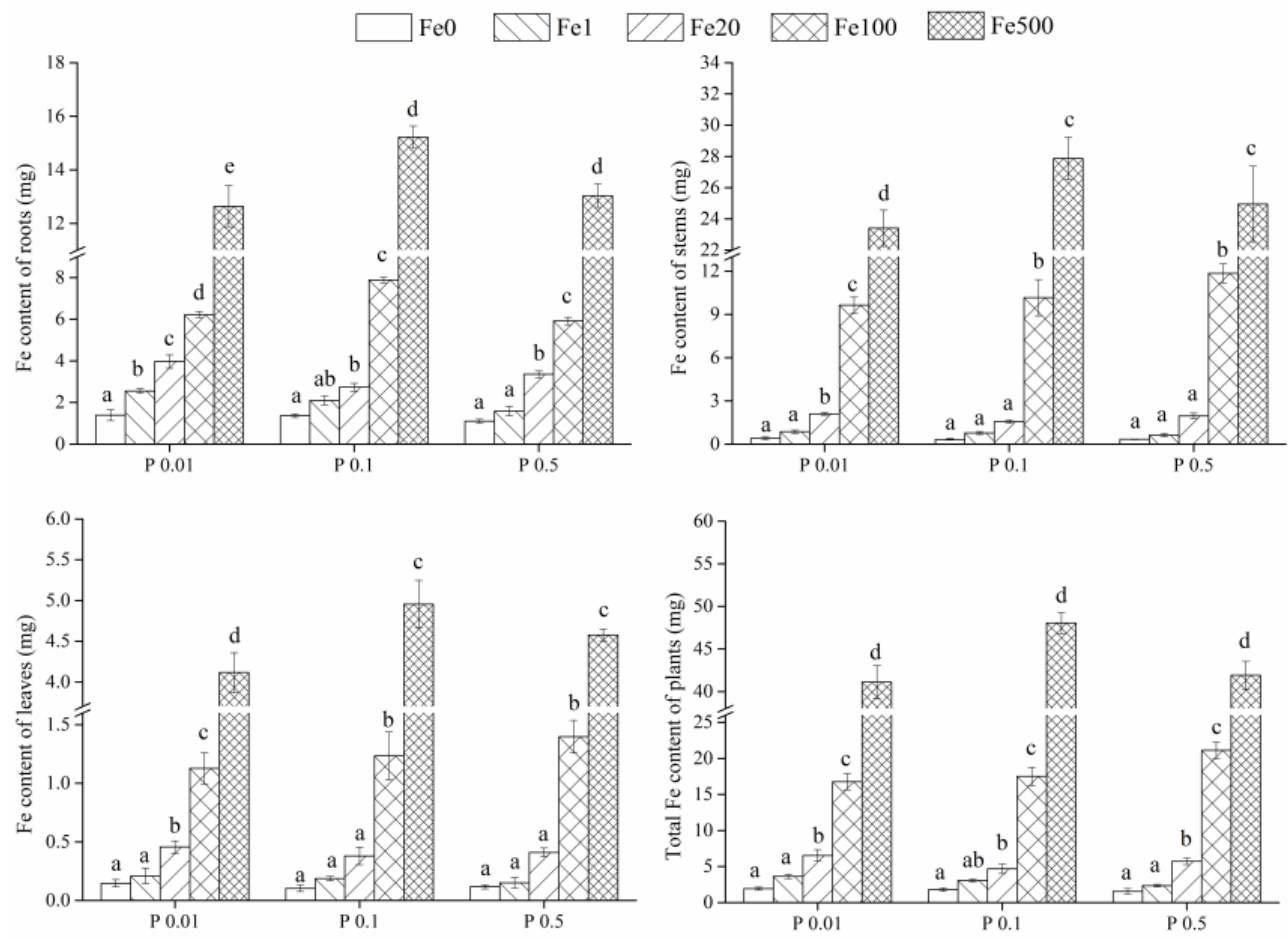

Figure 4. Effects of $\mathrm{Fe}^{2+}$ and $\mathrm{P}$ on roots, stems, leaves, and total Fe contents of G. spiculosa. Values (mean $\pm \mathrm{SE}, n=3$ ) followed by different letters designate significant differences $(p<0.05)$ between $\mathrm{Fe}^{2+}$ concentrations for a given $\mathrm{P}$ level $(\mathrm{a}, \mathrm{b}, \mathrm{c}, \mathrm{d})$.

Mn content in stems was significantly higher than in roots (1.04-4.35 times) and leaves (1.03-2.31 times) (Figure 5). In contrast to Fe and P, total Mn content of Fe 0 and Fe 1 treatments at any given $\mathrm{P}$ level was greater than others. The total Mn content in P 0.01 of Fe $0-\mathrm{Fe} 20$ was higher than P 0.1 and P 0.5 treatments, and higher in the Fe 100/P 0.5 and Fe 500/P 0.1 treatments. Plants grown in the Fe 500 treatment had the lowest total Mn content $(23.1 \%-41.1 \%$ of other treatments).

Stems (1.6-3.7 times) and leaves (1.4-2.9 times) had greater P content than roots for the same treatments (Figure 6). P content in each tissue type increased with $\mathrm{Fe}^{2+}$ addition until $\mathrm{Fe} 100$ and Fe 500 treatments, which showed a downward trend. The total P content of P 0.01 treatment was higher than the other P levels except the Fe 0 treatment. Among five Fe concentrations at a given $\mathrm{P}$ level, total $\mathrm{P}$ content of Fe 1 was greater and greatest in the Fe 20 treatments. 

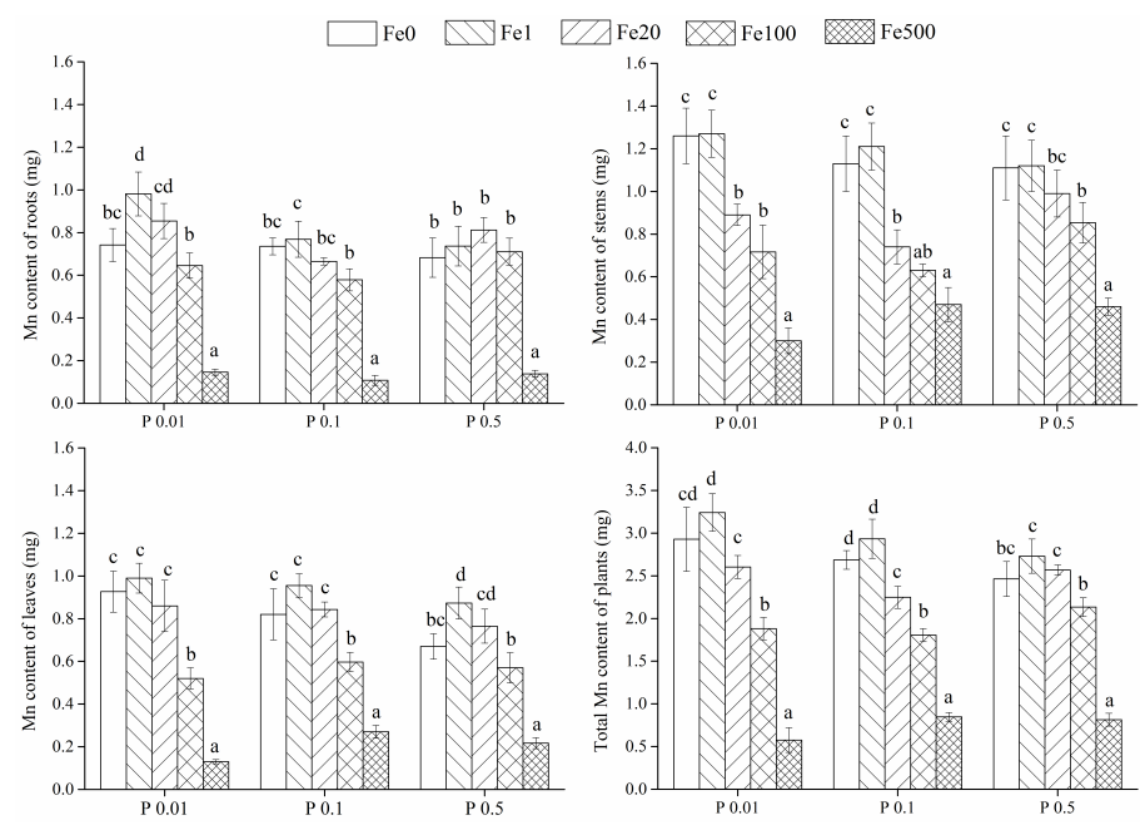

Figure 5. Effects of $\mathrm{Fe}^{2+}$ and $\mathrm{P}$ on roots, stems, leaves, and total Mn contents of G. spiculosa. Values (mean $\pm \mathrm{SE}, n=3$ ) followed by different letters designate significant differences $(p<0.05)$ between $\mathrm{Fe}^{2+}$ concentrations for a given $\mathrm{P}$ level $(\mathrm{a}, \mathrm{b}, \mathrm{c}, \mathrm{d})$.
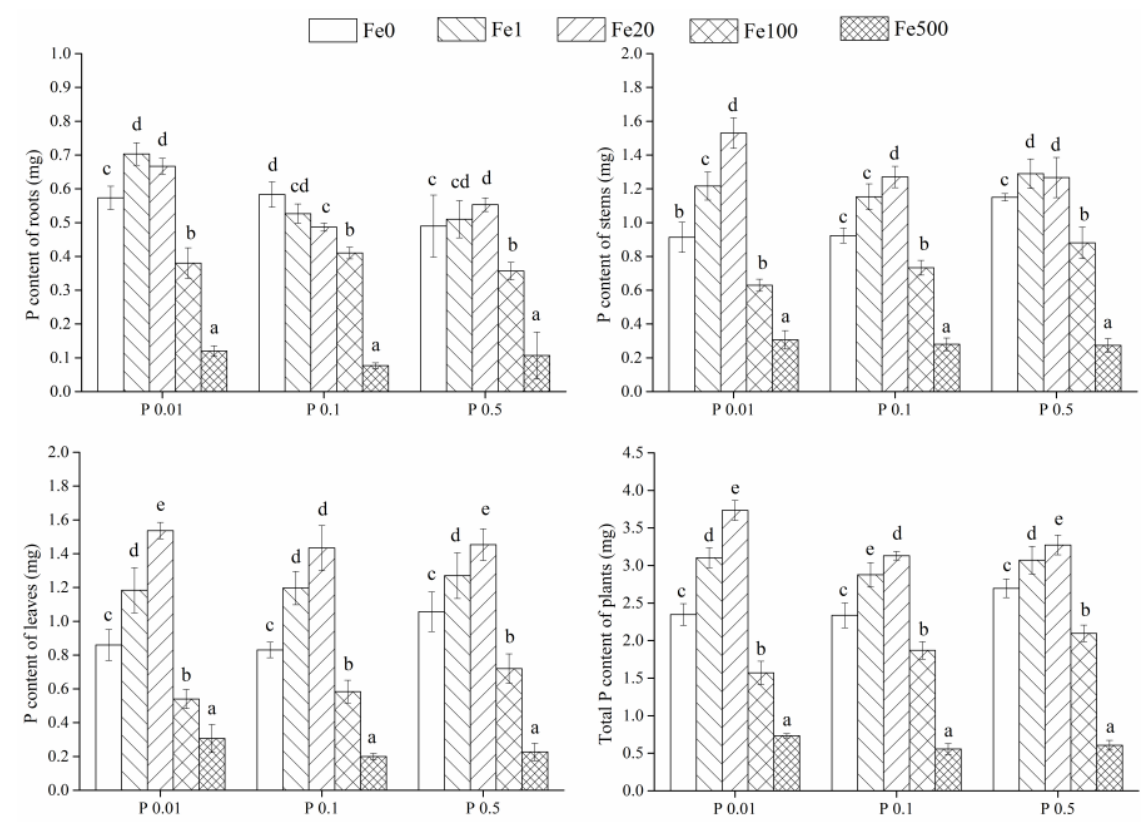

Figure 6. Effects of $\mathrm{Fe}^{2+}$ and $\mathrm{P}$ on roots, stems, leaves and total $\mathrm{P}$ contents of G. spiculosa. Values (mean $\pm \mathrm{SE}, n=3$ ) followed by different letters designate significant differences $(p<0.05)$ between $\mathrm{Fe}^{2+}$ concentrations for a given $\mathrm{P}$ level $(\mathrm{a}, \mathrm{b}, \mathrm{c}, \mathrm{d})$.

There were close correlations between iron plaque and total Fe, Mn, P content in plants. For total Fe content, a positive correlation was observed with iron plaque (Figure $7 \mathrm{a}, r^{2}=0.86$ ). Curviliner correlation between iron plaque and total Mn content (Figure $7 \mathrm{c}, r^{2}=0.89$ ) was significant. The total $\mathrm{P}$ content in plants were also significantly correlated with iron plaque (Figure $7 \mathrm{~b}, r^{2}=0.84$ ). 

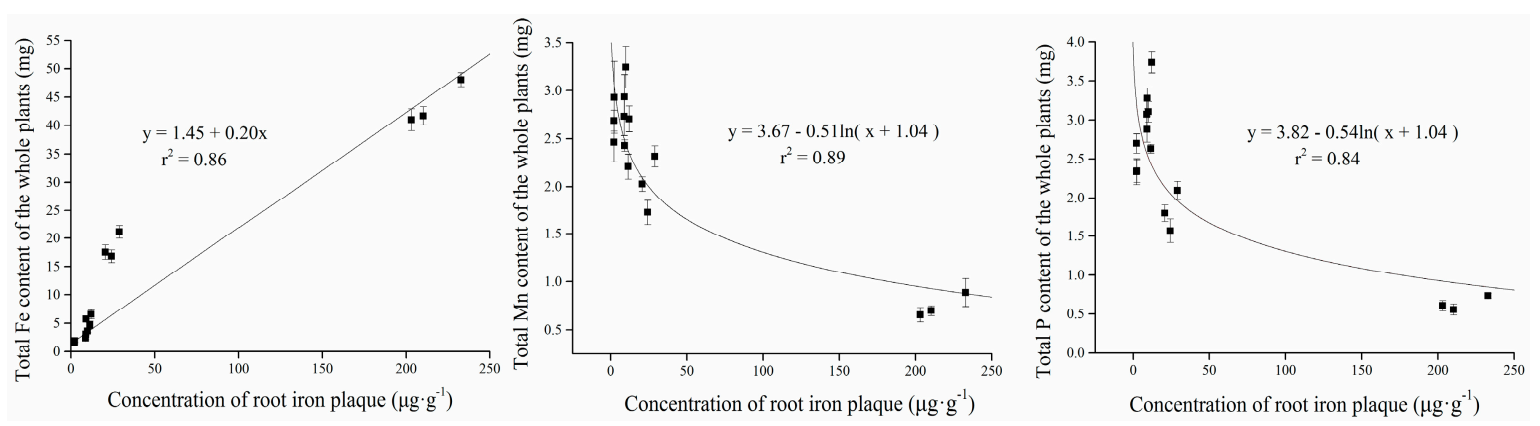

Figure 7. Relationship between the concentration of root iron plaque and total Fe content, total P content, and total Mn content of the whole plant. Data were means \pm SE $(n=3)$.

\subsection{Translocation and Acquisition Efficiency of Fe, Mn, and $P$}

As expected, Fe translocation in stems was significantly increased with the increasing iron in the solution (Table 3). The distribution of Fe in leaves was obviously lower than stems. The P translocation in stems and leaves was not as significant as in Fe, but data of Fe 1 and Fe 20 concentrations were higher than other Fe treatments. The Mn translocation in stems and leaves was similar between those treatments, and the distribution of $\mathrm{Mn}(22.4 \%-37.5 \%)$ and $\mathrm{P}(30.0 \%-44.9 \%)$ in leaves was higher than that of $\mathrm{Fe}(5.7 \%-10.9 \%)$.

The responses of FeAE were similar to the Fe translocation between Fe treatments for a given $\mathrm{P}$ level, which showed a positive correlation with Fe applied. For the difference of FeAE between three $\mathrm{P}$ levels, higher values were found in P 0.1 treatment of Fe 0-Fe 500, except there was no difference found in Fe 20. The results of MnAE and PAE were similar in terms of translocation, with higher MnAE in Fe 1 and PAE in Fe 1-Fe 20 treatments. For three P levels, the difference between FeAE, MnAE and PAE were not significant. 
Table 3. Effect of Fe and P on the translocation of Fe, Mn, and P from roots to the stems and leaves, and acquisition efficiency of Fe, Mn, and P (FeAE, MnAE, and PAE).

\begin{tabular}{|c|c|c|c|c|c|c|c|c|c|c|}
\hline \multicolumn{11}{|c|}{ Translocation (\%) and Acquisition Efficiency of Fe, Mn, and P (FeAE, MnAE, and PAE, mg.g $\left.{ }^{-1}\right)$} \\
\hline \multicolumn{2}{|c|}{ Treatements } & \multicolumn{3}{|c|}{ Fe } & \multicolumn{3}{|c|}{ Mn } & \multicolumn{3}{|c|}{$\mathbf{P}$} \\
\hline Fe & $\mathbf{P}$ & Stems & Leaves & FeAE & Stems & Leaves & MnAE & Stems & Leaves & PAE \\
\hline \multirow{3}{*}{ Fe 0} & P 0.01 & $20.5 \pm 3.3 \mathrm{a}$ & $7.6 \pm 1.6 \mathrm{ab}$ & $3.8 \pm 0.3 \mathrm{a}$ & $43.0 \pm 6.7 \mathrm{a}$ & $31.6 \pm 0.7 \mathrm{a}$ & $5.8 \pm 0.2 \mathrm{bc}$ & $38.9 \pm 7.9 \mathrm{a}$ & $36.6 \pm 9.2 \mathrm{a}$ & $4.6 \pm 0.3 \mathrm{ab}$ \\
\hline & P 0.1 & $18.5 \pm 4.9 \mathrm{a}$ & $5.7 \pm 0.8 \mathrm{a}$ & $4.1 \pm 0.2 \mathrm{a}$ & $42.1 \pm 9.4 \mathrm{ab}$ & $30.5 \pm 0.9 \mathrm{ab}$ & $6.3 \pm 0.4 \mathrm{ab}$ & $39.5 \pm 4.4 \mathrm{a}$ & $35.5 \pm 4.6 \mathrm{a}$ & $5.5 \pm 0.5 \mathrm{ab}$ \\
\hline & P 0.5 & $21.8 \pm 2.5 \mathrm{a}$ & $7.5 \pm 0.7 \mathrm{a}$ & $3.7 \pm 0.4 \mathrm{a}$ & $45.1 \pm 6.7 \mathrm{a}$ & $27.2 \pm 0.5 \mathrm{a}$ & $5.6 \pm 0.4 \mathrm{~b}$ & $42.6 \pm 2.2 \mathrm{a}$ & $39.2 \pm 9.2 \mathrm{a}$ & $6.2 \pm 0.5 b c$ \\
\hline \multirow[b]{2}{*}{$\mathrm{Fe} 1$} & P 0.01 & $23.9 \pm 6.4 \mathrm{a}$ & $5.8 \pm 0.7 \mathrm{a}$ & $6.8 \pm 0.2 \mathrm{ab}$ & $39.2 \pm 6.6 \mathrm{a}$ & $30.5 \pm 1.2 \mathrm{a}$ & $7.6 \pm 0.3 c$ & $39.2 \pm 8.3 a$ & $38.1 \pm 10.2 \mathrm{a}$ & $8.8 \pm 0.2 b$ \\
\hline & P 0.1 & $25.4 \pm 7.2 \mathrm{a}$ & $6.1 \pm 0.5 \mathrm{ab}$ & $7.9 \pm 0.6 \mathrm{~b}$ & $41.2 \pm 8.0 \mathrm{ab}$ & $32.6 \pm 3.5 \mathrm{ab}$ & $7.4 \pm 0.8 \mathrm{~b}$ & $40.1 \pm 7.7 \mathrm{a}$ & $41.6 \pm 9.9 \mathrm{ab}$ & $7.4 \pm 0.9 \mathrm{bc}$ \\
\hline \multirow{3}{*}{ Fe 20} & P 0.01 & $32.2 \pm 6.3 \mathrm{a}$ & $7.0 \pm 0.9 \mathrm{a}$ & $14.0 \pm 0.7 \mathrm{~b}$ & $34.2 \pm 3.8 \mathrm{a}$ & $33.1 \pm 5.1 \mathrm{a}$ & $5.9 \pm 0.2 b c$ & $41.0 \pm 9.1 \mathrm{a}$ & $41.2 \pm 4.8 \mathrm{a}$ & $8.1 \pm 0.8 c$ \\
\hline & P 0.1 & $33.6 \pm 5.6 \mathrm{a}$ & $8.1 \pm 1.1 \mathrm{bc}$ & $13.8 \pm 0.8 \mathrm{c}$ & $32.9 \pm 5.6 \mathrm{a}$ & $37.5 \pm 6.5 \mathrm{~b}$ & $6.6 \pm 0.3 \mathrm{ab}$ & $39.8 \pm 6.3 \mathrm{a}$ & $44.9 \pm 6.9 \mathrm{~b}$ & $7.8 \pm 0.6 c$ \\
\hline & P 0.5 & $34.2 \pm 8.4 \mathrm{a}$ & $7.2 \pm 0.7 \mathrm{a}$ & $12.5 \pm 0.5 \mathrm{c}$ & $38.5 \pm 3.5 \mathrm{a}$ & $29.8 \pm 4.5 \mathrm{a}$ & $5.3 \pm 0.2 b$ & $38.7 \pm 9.4 \mathrm{a}$ & $44.4 \pm 10.5 \mathrm{a}$ & $7.1 \pm 0.5 c$ \\
\hline \multirow{3}{*}{ Fe 100} & P 0.01 & $57.4 \pm 9.3 \mathrm{~b}$ & $6.7 \pm 0.4 \mathrm{a}$ & $49.0 \pm 2 c$ & $38.3 \pm 9.5 \mathrm{a}$ & $27.7 \pm 0.9 \mathrm{a}$ & $5.4 \pm 0.5 \mathrm{~b}$ & $44.5 \pm 4.3 \mathrm{a}$ & $34.5 \pm 9.3 \mathrm{a}$ & $4.9 \pm 0.3 \mathrm{ab}$ \\
\hline & P 0.1 & $58.1 \pm 7.2 \mathrm{~b}$ & $7.0 \pm 0.6 \mathrm{ab}$ & $61.2 \pm 4.7 \mathrm{~d}$ & $34.8 \pm 3.0 \mathrm{a}$ & $33.1 \pm 1.1 \mathrm{ab}$ & $6.3 \pm 0.6 \mathrm{ab}$ & $40.1 \pm 3.6 \mathrm{a}$ & $37.2 \pm 5.7 \mathrm{a}$ & $5.7 \pm 0.4 \mathrm{ab}$ \\
\hline & Р 0.5 & $56.1 \pm 6.5 b$ & $6.6 \pm 0.8 \mathrm{a}$ & $51.8 \pm 1.8 \mathrm{~d}$ & $39.9 \pm 4.8 \mathrm{a}$ & $26.8 \pm 3.8 \mathrm{a}$ & $5.8 \pm 0.5 \mathrm{~b}$ & $48.9 \pm 9.3 \mathrm{a}$ & $30.0 \pm 6.8 \mathrm{a}$ & $5.1 \pm 0.2 \mathrm{~b}$ \\
\hline \multirow[b]{2}{*}{ Fe 500} & P 0.01 & $56.9 \pm 8.2 b$ & $10.0 \pm 1.3 \mathrm{~b}$ & $265.7 \pm 44.1 \mathrm{~d}$ & $51.7 \pm 4.0 \mathrm{a}$ & $22.4 \pm 5.4 \mathrm{a}$ & $4.8 \pm 0.1 \mathrm{a}$ & $41.8 \pm 5.5 \mathrm{a}$ & $41.8 \pm 8.7 \mathrm{a}$ & $3.9 \pm 0.6 \mathrm{a}$ \\
\hline & P 0.1 & $58.0 \pm 7.9 \mathrm{~b}$ & $10.3 \pm 0.8 c$ & $350.4 \pm 18.9 \mathrm{e}$ & $55.3 \pm 6.2 \mathrm{~b}$ & $31.8 \pm 0.4 \mathrm{a}$ & $5.3 \pm 0.3 \mathrm{a}$ & $50.3 \pm 3.8 \mathrm{a}$ & $35.9 \pm 1.8 \mathrm{a}$ & $4.6 \pm 0.3 \mathrm{a}$ \\
\hline
\end{tabular}

Notes: The data of FeAE were square transformed before parametric analysis. Data are means \pm SE $(n=3)$. For each parameter values followed by different letters designate significant differences $(p<0.05)$ between $\mathrm{Fe}^{2+}$ concentrations for a given $\mathrm{P}$ level $(\mathrm{a}, \mathrm{b}, \mathrm{c}, \mathrm{d})$. 


\section{Discussion}

\subsection{Iron Plaque Formation, SEM and EDS Analysis}

Iron in the aquatic environment can not only directly participates in the physiological processes of wetland plants, but also forms iron plaque indirectly affecting the absorption and translocation of nutrients. Some research has shown that nutrient limitation may be the major factor to the growth of wetland plants [25]. In present study, the physico-chemical properties of iron plaque of G. spiculosa were characterized by SEM-EDX (Figures 2 and 3). The elements present in the plaque included essential plant nutrients, such as $\mathrm{Fe}, \mathrm{O}, \mathrm{Mn}, \mathrm{P}, \mathrm{S}, \mathrm{Mg}$, and $\mathrm{Al}$. The amounts of iron plaque on the root surface were significantly affected by amounts of Fe supplied in the culture medium. Iron plaque formation on the roots increased with increasing levels of iron in the growth medium. Additionally, the root dry matter of G. spiculosa was declining with the increasing iron additon (Table 2), indicating that large amount of iron plaque harmed the growth of plant roots. Our results further showed that iron plaque formation was highest at the lower P treatments, which is comparable with data reported for rice $[9,26]$. Fu et al. [27] reported that $\mathrm{P}$ deficiency in the rhizosphere could increase the oxidizing capability of rice roots, which was associated with production of reactive oxygen species, increase in antioxidant enzyme activity, and the release of $\mathrm{O}_{2}$ and oxidative substances from the root. The $\mathrm{Fe}^{2+}$ around the rhizosphere is oxidized by these oxidizing substances to $\mathrm{Fe}^{3+}$ that precipitates as orange iron plaque accumulation on the root surface of aquatic plants and on soil particles in the rhizosphere [28]. For wetland species, however, few studies focus on the iron plaque formation on the root surface under P-deficiency conditions $[9,26]$.

\subsection{Uptake, Translocation of Fe and FeAE}

In wetland environments, Fe immobility is highly variable. Plants therefore need a tight regulation of Fe uptake, transport, and storage to ensure balanced development by avoiding both Fe deficiency and toxicity [29]. The total Fe contents of the plants significantly increased with the application of Fe. Meanwhile, our results indicated that wetland plants have high innate tolerance to iron in their habitats, which demonstrates the reasons for growing wetland plants in iron ore mining and other iron-contamined environments [30]. All plants were collected from areas that had not been exposed to high levels of $\mathrm{Fe}^{2+}$. As a result, $\mathrm{Fe}$ tolerance would have to be innate. In response to Fe overload, plants express a series of Fe homeostasis-related genes, including those encoding for ferritin and a common protein for Fe storage [31]. The transporters are generally divided into low-affinity Fe transport systems and high-affinity Fe transport systems. Low-affinity transport systems take up sufficient Fe in high levels of Fe, meanwhile preventing Fe overload. In contrast, high-affinity Fe transport systems are activated by Fe deficiency conditions [32,33]. The formation of iron plaque under P-deficiency conditions had a large effect on Fe uptake of roots. Furthermore, the expression of ferritin genes in Arabidopsis plants can be effectively induced by P-deficiency conditions, such as encoding of NAS3 and ZIP5 for metal transport [21]. Moreover, the induction of genes involved in the transport and storage inside the plant in the forms of chelated iron, by metallothioneins, nicotianamine, and ferritin, suggesting a global and consistent plant response to P-deficiency [34].

Our results futher suggested the translocation was affected. The Fe translocation process involves various $\mathrm{Fe}$ transport components, such as those involved with long-distance transport within the vascular system (from root to shoot, cotyledons to young shoots), and short-distance transport within the cells (intracellularly in the symplast), to final destination targets within cells (compartment or biomolecules) [29]. These transport processes and strategies aim to protect and maintain plants' health. In this study, with increasing Fe supply, the content and translocation of Fe in the stems gradually increased, but Fe in leaves remained stable (5.7\%-8.1\%), except for the highest exposure (Fe 500: $10.0 \%-10.9 \%$ ). Wetland plants seem to generally engage in an "exclusion" strategy, in which metals in aboveground parts are maintained at a constant low levels until a critical external concentration is reached [10]. In our experiment, leaf-wilting and desiccation were observed at the Fe 500 treatment, 
and those are well-known symptoms, which may have caused unrestricted metal transport. Excessive absorption of $\mathrm{Fe}^{2+}$ by roots and subsequent translocation to leaves causes an elevated production of toxic oxygen radicals, which destroys cell structural components and damages physiological processes [35]. The critical Fe content depends on plant age. The color of leaves could be changed from orange to rusty brown with excessive Fe content in plant, especially in older leaves [36,37]. It is most likely that the result of damage to the root system, and the rapid reduction of root biomass was the best evidence. Consistent with our study, Batty et al. [38] found that the roots of aquatic plants were inhibited under conditions of excessive Fe supply, including root flaccidity and reduced root branching.

\subsection{Uptake, Translocation of $M n$ and $M n A E$}

Mn is essential for plant metabolism and develpment, and exists in oxidation states II, III, and IV inside about 35 enzymes of a plant cell [39]. Mn mainly achieves two functions in proteins: (1) it acts as a catalyzing active metal, or (2) it shows an activating role on enzymes [40]. The concentration of $\mathrm{Mn}$ in the nutrient solution was suitable for plant growth, so it can be used to detect the effects of $\mathrm{Fe}$ and $\mathrm{P}$ on the absorption of micronutrients. The Mn content was increased with the treatment of $1 \mathrm{mg} \cdot \mathrm{L}^{-1} \mathrm{Fe}$, which concentration was close to the natural habitat of the plants. The results indicated that large amount of agricultural drainage water containing iron-rich groundwater would promote the growth of wetland plants, due to the high iron tolerance of plants. The results confirmed that the Mn uptake was promoted by iron addition within the natural range, but significantly suppressed when iron concentration become excessively high. The mechanism by which plaque affects the precipitation and uptake of $\mathrm{Mn}, \mathrm{Pb}$, and $\mathrm{Zn}$ may involve the absorption of metals onto the large surface plaque area [12,41]. Inside the plants, an Fe transport protein (RcITP) binds preferentially Fe(III) over Fe(II), but it also forms compleses with $\mathrm{Mn}, \mathrm{Zn}$, and $\mathrm{Cu}$, which also promote $\mathrm{Mn}$ absorption and migration at the same time [42]. Kruger et al. [42] further showed that a thick iron plaque may have limited capacity for the absorption of Mn and other metals, which was consistent with our study. Other results have also shown that the concentrations of $\mathrm{Mn}$ tends to be reduced under similar conditions, suggesting that uptake is particularly affected by large amounts of iron plaque [43]. Batty et al. [41] found that the Mn concentration in the absence of plaque was higher than when plaque was present. The EDX analysis in our study also showed that large amounts of Mn existed on the surface of the plaque, suggesting that abundant iron plaque acted as a barrier for micronutrients by forming a complex precipitation or adsorption on the plaque surface.

The absorption and translocation of micronutrients seemed to be sensitive to high concentrations of Fe application. Studies with Lynch and Clair [44], and Socha and Guerinot [45], have shown that Mn deficiency can be caused by multiple factors including high concentrations of other minerals in the soil, such as $\mathrm{Fe}, \mathrm{Mg}, \mathrm{Ca}$, and P. The results of Ghasemi-Fasaei et al. [46] showed that foliar application of Fe on chickpea decreased Mn uptake owing to the antagonistic effect of Fe on translocation of Mn from root to shoot. Similar to Mn, the uptake and translocation of Zn was also inhibited by Fe in the solution $[47,48]$. Mn, Zn, or Cu deficiency may be induced following excessive Fe fertilization due to uptake of relatively large amounts of Fe [49]. Hayes et al. [48], showed a negative relationship between leaf Mn and total soil P concentration along a bay in western Australia. Soluble P in the rhizosphere can form coprecipitation with $\mathrm{Fe}^{3+}$ and $\mathrm{Mn}^{4+}$, which can bind to amorphous oxyhydroxides in root plaques. The conclusion was consistent with our results: total Mn content in plants of P 0.5 was lower than the other $\mathrm{P}$ treatments. In general, plants receive higher MnAE by roots and transportation to aboveground with the Fe 1 treatment.

\subsection{Uptake, Translocation of $P$ and $P A E$}

Excessive fertilization of agricultural land has resulted in large losses of $P$ from paddy field to the aquatic environment. In recent years, interactions between Fe and $P$ have already been utilized in technological applications. For example, studies have shown that Fe-coated sand as a liner in drainage systems could reduce P loading of surface water [50]. The formation of iron plaque on the root surface 
of wetlands has a number of functions, such as nutrient and contaminant uptake. Khan et al. [5] reported that iron plaque has a high capacity to bind $\mathrm{P}$ in wetlands, and the sediments Eh, $\mathrm{P}$, and Fe cycling have close links in lake ecosystems. Furthermore, Fe sludge and Fe-rich groundwater could be used as reactive materials to control the eutrophication water bodies, which could bound a large amount of P [23]. Apart from the potential role of iron plaque in changing the bioavailability of metals in the rhizosphere of wetland plants, iron plaque is believed to be important in plant $\mathrm{P}$ uptake and translocation. In our experiment, P 0.01 during the last two weeks was intended to simulate the P-deficient condition of G. spiculosa grown in solution. However, in retrospect, the plants may have obtained sufficient amounts of $P$ from the nutrient solution in the initial three weeks, also aided by $\mathrm{P}$ adsorbed in the iron plaque. Similar results were found for common reed (Phragmites australis (Cav.) Trin ex. Steudel.), in which the amount of $\mathrm{P}$ adsorbing increased with the amount of plaque formation on the roots $[8,38]$. Even without $\mathrm{P}$ supplied in the solution, $\mathrm{P}$ concentrations in rice seedings were not deficient at the background levels of Fe applied [9].

Hu et al. [22] showed that $\mathrm{P}$ deficiency in habitats results in an increase in plant root length and porosity, thereby increasing aquatic plants ROL that subsequently would oxidize higher amounts of $\mathrm{Fe}^{2+}$ and form root plaque. Although previous studies indicated that root porosity, ROL, and Fe plaque are mainly controlled genetically [51], wastewater as an environmental stress or can change these properties. High strength wastewater, such as the agricultural drainage water from paddy fields, significantly decreased ROL and root porosity, but high level of iron promoted the formation of iron plaque, further enhancing the absorption of $P$ from habitats. The success of iron addition in order to regulate $\mathrm{P}$ release can be calculated by using the Fe:P ratio in the sediment pore water, which ranging from $1-15$ of pore water ratio $[52,53]$. The pore water Fe:P ratio provides a good prognosis for both the restoration of water quality and biodiversity after restoration measures. Therefore, these reactive materials can be used for trapping $\mathrm{P}$ in the soil solution by using iron rich groundwater for irrigation or adding the reactive materials in lakes or wetlands when agricultural drainage water exports into the surrounding ecosystems.

Apart from enhacing $\mathrm{P}$ absorption from habitats, iron plaque promoted $\mathrm{P}$ translocation to the aboveground. Unlike other elements, the P content of stems and leaves was nearly two times that of the roots for a given Fe and P treatment (Figure 6), and the PAE of Fe 1-Fe 20 showed much higher values. P plays a crucial role in plant cell division, growth, and biomass accumulation. Our results implied that iron-rich groundwater flowing into wetlands may be beneficial to P uptake and transfer to abovegound biomass in wetland plants. However, the P content was reduced significantly when the external Fe concentration was over $100 \mathrm{mg} \cdot \mathrm{L}^{-1}$ in our study, partly because the roots of plants were harmed and large amounts of iron oxyhydroxides in the root plaque bound sequestrated $\mathrm{P}$. Stimulation of development of iron plaque on the root surface has been used to reduce the toxic effects of $\mathrm{As}, \mathrm{Pb}$, and $\mathrm{Cd}$, and the effect of $\mathrm{P}$ decreased metal desorption, solubility, and bioavailability in the rhizosphere; this even enhanced tolerance to heavy metals $[20,54]$.

\section{Conclusions}

Our findings provided mechanistic insights into Fe biogeochemistry in the rhizosphere of G. spiculosa in relation to P uptake, $\mathrm{Mn}$, and other micronutrients. The presence of excess $\mathrm{Fe}^{2+}$ in the aquatic environment induced the formation of iron plaque on the root surface. The amount of iron plaque increased with increasing $\mathrm{Fe}^{2+}$ supply, and P-deficiency promoted its production. Iron plaque on the root surface could function as a reservoir for nutrients, but inhibited element accumulation and translocation in the plants when present as a thick cover on the roots. In the presence of excessive iron plaque, the uptake and translocation of Fe in plants was decreased significantly. The absorption of Mn was particularly affected by iron plaque. Formation of iron plaque enhanced the P utilization until the external iron concentration exceeded $100 \mathrm{mg} \cdot \mathrm{L}^{-1}$. 
Acknowledgments: We sincerely thank Beth A Middleton of United States Geological Survey for her constructive comments on the early version of this manuscript. This research was supported by Minstry of Science and Technology of People's Republic of China (2016YFA0602303), the National Key Research \& Development Program of China (2016YFC0500408), National Natural Science Foundation of China $(41771120,41271107,41471079)$, and the Northeast Institute of Geography and Agroecology, CAS (IGA-135-05).

Author Contributions: Conceived and designed the experiments: X.J., M.J., Y.Z., and X.L. Performed the experiments: X.J., Y.L., X.T., L.Q. Analyzed the data and prepared the manuscript: X.J., M.J. and M.L.O. revised it. All authors read and approved the manuscript.

Conflicts of Interest: All authors have no conflict of interests to any other parties.

\section{References}

1. Messer, T.L.; Burchell, M.R., II; Birgand, F.; Broome, S.W.; Chescheir, G. Nitrate removal potential of restored wetlands loaded with agricultural drainage water: A mesocosm scale experimental approach. Ecol. Eng. 2017, 106, 541-554. [CrossRef]

2. Dunne, E.J.; Coveney, M.F.; Hoge, V.R.; Conrow, R.; Naleway, R.; Lowe, E.F.; Battoe, L.E.; Wang, Y. Phosphorus removal performance of a large-scale constructed treatment wetland receiving eutrophic lake water. Ecol. Eng. 2015, 79, 132-142. [CrossRef]

3. Vymazal, J.; Brezinova, T. The use of constructed wetlands for removal of pesticides from agricultural runoff and drainage: A review. Environ. Int. 2015, 75, 11-20. [CrossRef] [PubMed]

4. Wang, C.Y.; Sample, D.J.; Day, S.D.; Grizzard, T.J. Floating treatment wetland nutrient removal through vegetation harvest and observations from a field study. Ecol. Eng. 2015, 78, 15-26. [CrossRef]

5. Khan, N.; Seshadri, B.; Bolan, N.; Saint, C.P.; Kirkham, M.B.; Chowdhury, S.; Yamaguchi, N.; Lee, D.Y.; Li, G.; Kunhikrishnan, A.; et al. Chapter one-root iron plaque on wetland plants as a dynamic pool of nutrients and contaminants. Adv. Agron. 2016, 138, 1-96.

6. Allen, W.C.; Hook, P.B.; Biederman, J.A.; Stein, O.R. Temperature and wetland plant species effects on wastewater treatment and root zone oxidation. J. Environ. Qual. 2002, 31, 1010-1016. [CrossRef] [PubMed]

7. Liang, Y.; Zhu, Y.G.; Xia, Y.; Li, Z.; Ma, Y. Iron plaque enhances phosphorus uptake by rice (Oryza sativa) growing under varying phosphorus and iron concentrations. Ann. Appl. Biol. 2006, 149, 305-312. [CrossRef]

8. Liu, W.J.; Zhu, Y.G.; Smith, F.A.; Smith, S.E. Do phosphorus nutrition and iron plaque alter arsenate (As) uptake by rice seedlings in hydroponic culture? New Phytol. 2004, 162, 481-488. [CrossRef]

9. Kobayashi, T.; Nishizawa, N.K. Iron uptake, translocation, and regulation in higher plants. Annu. Rev. Plant. Biol. 2012, 63, 131-152. [CrossRef] [PubMed]

10. Sebastian, A.; Prasad, M.N. Iron plaque decreases cadmium accumulation in Oryza sativa L. and serves as a source of iron. Plant Biol. 2016, 18, 1008-1015. [CrossRef] [PubMed]

11. Hansel, C.M.; Fendorf, S.; Sutton, S.; Newville, M. Characterization of Fe plaque and associated metals on the roots of mine-waste impacted aquatic plants. Environ. Sci. Technol. 2001, 35, 3863-3868. [CrossRef] [PubMed]

12. Machado, W.; Gueiros, B.B.; Lisboa-Filho, S.D.; Lacerda, L.D. Trace metals in mangrove seedlings: Role of iron plaque formation. Wetlands Ecol. Manag. 2005, 13, 199-206. [CrossRef]

13. $\mathrm{Xu}, \mathrm{D} . ; \mathrm{Xu}, \mathrm{J} . ; \mathrm{He}, \mathrm{Y}$.; Huang, P.M. Effect of iron plaque formation on phosphorus accumulation and availability in the rhizosphere of wetland plants. Water Air Soil. Pollut. 2008, 200, 79-87. [CrossRef]

14. Ye, Z.; Baker, A.J.; Wong, M.H.; Willis, A.J. Zinc, lead and cadmium accumulation and tolerance in Typha latifolia as affected by iron plaque on the root surface. Aquat. Bot. 1998, 61, 55-67. [CrossRef]

15. Tripathi, R.D.; Tripathi, P.; Dwivedi, S.; Kumar, A.; Mishra, A.; Chauhan, P.S.; Norton, G.J.; Nautiyal, C.S. Roles for root iron plaque in sequestration and uptake of heavy metals and metalloids in aquatic and wetland plants. Metallomics 2014, 6, 1789-1800. [CrossRef] [PubMed]

16. Otte, M.; Rozema, J.; Koster, L.; Haarsma, M.; Broekman, R. Iron plaque on roots of Aster tripolium L.: Interaction with zinc uptake. New Phytol. 1989, 111, 309-317. [CrossRef]

17. Zhang, X.; Zhang, F.; Mao, D. Effect of iron plaque outside roots on nutrient uptake by rice (Oryza sativa L.): Phosphorus uptake. Plant Soil 1999, 209, 187-192. [CrossRef]

18. Raghothama, K. Phosphate acquisition. Annu. Rev. Plant Biol. 1999, 50, 665-693. [CrossRef] [PubMed]

19. Lambers, H.; Hayes, P.E.; Laliberte, E.; Oliveira, R.S.; Turner, B.L. Leaf manganese accumulation and phosphorus-acquisition efficiency. Trends Plant Sci. 2015, 20, 83-90. [CrossRef] [PubMed] 
20. Yang, Y.; Chen, R.; Fu, G.; Xiong, J.; Tao, L. Phosphate deprivation decreases cadmium (Cd) uptake but enhances sensitivity to $\mathrm{Cd}$ by increasing iron (Fe) uptake and inhibiting phytochelatins synthesis in rice (Oryza sativa). Acta Physiol. Plant. 2015, 38, 28. [CrossRef]

21. Hirsch, J.; Marin, E.; Floriani, M.; Chiarenza, S.; Richaud, P.; Nussaume, L.; Thibaud, M.C. Phosphate deficiency promotes modification of iron distribution in Arabidopsis plants. Biochimie 2006, 88, 1767-1771. [CrossRef] [PubMed]

22. Hu, Y.; Huang, Y.Z.; Liu, Y.Z. Influence of iron plaque on chromium accumulation and translocation in three rice (Oryza sativa L.) cultivars grown in solution culture. Chem. Ecol. 2014, 30, 29-38. [CrossRef]

23. Chardon, W.J.; Groenenberg, J.E.; Temminghoff, E.J.; Koopmans, G.F. Use of reactive materials to bind phosphorus. J. Environ. Qual. 2012, 41, 636-646. [CrossRef] [PubMed]

24. Taylor, G.J.; Crowder, A. Use of the DCB technique for extraction of hydrous iron oxides from roots of wetland plants. Am. J. Bot. 1983, 70, 1254-1257. [CrossRef]

25. Yamauchi, M. Rice bronzing in Nigeria caused by nutrient imbalances and its control by potassium sulfate application. Plant Soil 1989, 117, 275-286. [CrossRef]

26. Hu, Y.; Li, J.H.; Zhu, Y.G.; Huang, Y.Z.; Hu, H.Q.; Christie, P. Sequestration of As by iron plaque on the roots of three rice (Oryza sativa L.) cultivars in a low-P soil with or without P fertilizer. Environ. Geochem. Hlth. 2005, 27, 169-176. [CrossRef] [PubMed]

27. Fu, Y.Q.; Yang, X.J.; Shen, H. The physiological mechanism of enhanced oxidizing capacity of rice (Oryza sativa L.) roots induced by phosphorus deficiency. Acta Physiol. Plant. 2014, 36, 179-190. [CrossRef]

28. Yang, J.; Tam, N.F.Y.; Ye, Z. Root porosity, radial oxygen loss and iron plaque on roots of wetland plants in relation to zinc tolerance and accumulation. Plant Soil 2013, 374, 815-828. [CrossRef]

29. Barton, L.L.; Abadia, J. Iron Nutrition in Plants and Rhizospheric Microorganisms; Springer Science \& Business Media: Dordrecht, The Netherlands, 2006; pp. 341-357.

30. Matthews, D.J.; Moran, B.M.; Otte, M.L. Screening the wetland plant species Alisma plantago-aquatica, Carex rostrata and Phalaris arundinacea for innate tolerance to zinc and comparison with Eriophorum angustifolium and Festuca rubra Merlin. Environ. Pollut. 2005, 134, 343-351. [CrossRef] [PubMed]

31. Petit, J.M.; Briat, J.F.; Lobréaux, S. Structure and differential expression of the four members of the Arabidopsis thaliana ferritin gene family. Biochem. J. 2001, 359, 575-582. [CrossRef] [PubMed]

32. Kaplan, J. Strategy and tactics in the evolution of iron acquisition. Semin. Hematol. 2002, 39, $219-226$. [CrossRef] [PubMed]

33. Van Ho, A.; Ward, D.M.; Kaplan, J. Transition metal transport in yeast. Annu. Rev. Microbiol. 2002, 56, 237-261. [CrossRef] [PubMed]

34. Abel, S. Phosphate sensing in root development. Curr. Opin. Plant Biol. 2011, 14, 303-309. [CrossRef] [PubMed]

35. Becker, M.; Asch, F. Iron toxicity in rice-Conditions and management concepts. J. Plant Nutr. Soil Sci. 2005, 168, 558-573. [CrossRef]

36. Yamanouchi, M.; Yoshida, S. Physiological Mechanism of Rice's Tolerance for Iron Toxicity; Plant Physiology Departemen of IRRI: Makati, Philippines, 1981; p. 21.

37. Fairhurst, T.; Witt, C.; Buresh, R.; Dobermann, A.; Fairhurst, T. Rice: A Practical Guide to Nutrient Management; The International Rice Research Institute (IRRI): Singapore, 2007; pp. 73-75.

38. Batty, L.C.; Younger, P.L. Effects of external iron concentration upon seedling growth and uptake of Fe and phosphate by the common reed, Phragmites australis (Cav.) Trin ex. Steudel. Ann. Bot.-Lond. 2003, 92, 801-806. [CrossRef] [PubMed]

39. Hebbern, C.A.; Laursen, K.H.; Ladegaard, A.H.; Schmidt, S.B.; Pedas, P.; Bruhn, D.; Schjoerring, J.K.; Wulfsohn, D.; Husted, S. Latent manganese deficiency increases transpiration in barley (Hordeum vulgare). Physiol. Plant. 2008, 135, 307-316. [CrossRef] [PubMed]

40. Hansch, R.; Mendel, R.R. Physiological functions of mineral micronutrients ( $\mathrm{Cu}, \mathrm{Zn}, \mathrm{Mn}, \mathrm{Fe}, \mathrm{Ni}, \mathrm{Mo}, \mathrm{B}, \mathrm{Cl})$. Curr. Opin. Plant Biol. 2009, 12, 259-266. [CrossRef] [PubMed]

41. Batty, L.; Baker, A.; Wheeler, B.; Curtis, C. The effect of $\mathrm{pH}$ and plaque on the uptake of $\mathrm{Cu}$ and $\mathrm{Mn}$ in Phragmites australis (Cav.) Trin ex. Steudel. Ann. Bot. 2000, 86, 647-653. [CrossRef]

42. Kruger, C.; Berkowitz, O.; Stephan, U.W.; Hell, R. A metal-binding member of the late embryogenesis abundant protein family transports iron in the phloem of Ricinus communis L. J. Biol. Chem. 2002, 277, 25062-25069. [CrossRef] [PubMed] 
43. Snowden, R.; Wheeler, B. Chemical changes in selected wetland plant species with increasing Fe supply, with specific reference to root precipitates and Fe tolerance. New Phytol. 1995, 131, 503-520. [CrossRef]

44. Lynch, J.P.; Clair, S.B.S. Mineral stress: The missing link in understanding how global climate change will affect plants in real world soils. Field Crop Res. 2004, 90, 101-115. [CrossRef]

45. Socha, A.L.; Guerinot, M.L. Mn-euvering manganese: The role of transporter gene family members in manganese uptake and mobilization in plants. Front. Plant. Sci. 2014, 5, 106. [CrossRef] [PubMed]

46. Ghasemi-Fasaei, R.; Ronaghi, A.; Maftoun, M.; Karimian, N.A.; Soltanpour, P.N. Iron-manganese interaction in chickpea as affected by foliar and soil application of iron in a calcareous soil. Commun. Soil Sci. Plan. 2005, 36, 1717-1725. [CrossRef]

47. Martínez-Cuenca, M.R.; Quiñones, A.; Iglesias, D.J.; Forner-Giner, M.Á.; Primo-Millo, E.; Legaz, F. Effects of high levels of zinc and manganese ions on Strategy I responses to iron deficiency in citrus. Plant Soil 2013, 373, 943-953. [CrossRef]

48. Hayes, P.; Turner, B.L.; Lambers, H.; Laliberté, E. Foliar nutrient concentrations and resorption efficiency in plants of contrasting nutrient-acquisition strategies along a 2-million-year dune chronosequence. J. Ecol. 2014, 102, 396-410. [CrossRef]

49. Ronaghi, A.; Ghasemi-Fasaei, R. Field evaluations of yield, iron-manganese relationship, and chlorophyll meter readings in soybean genotypes as affected by iron-ethylenediamine di-o-hydroxyphenylacetic acid in a calcareous soil. J. Plant. Nutr. 2007, 31, 81-89. [CrossRef]

50. Groenenberg, J.E.; Chardon, W.J.; Koopmans, G.F. Reducing phosphorus loading of surface water using iron-coated sand. J. Environ. Qual. 2013, 42, 250-259. [CrossRef] [PubMed]

51. Mei, X.Q.; Yang, Y.; Tam, N.F.Y.; Wang, Y.M.; Li, L. Roles of root porosity, radial oxygen loss, Fe plaque formation on nutrient removal and tolerance of wetland plants to domestic wastewater. Water Res. 2014, 50, 147-159. [CrossRef] [PubMed]

52. Geurts, J.J.M.; Smolders, A.J.P.; Verhoeven, J.T.A.; Roelofs, J.G.M.; Lamers, L.P.M. Sediment Fe:PO4 ratio as a diagnostic and prognostic tool for the restoration of macrophyte biodiversity in fen waters. Freshw. Biol. 2008, 53, 2101-2116. [CrossRef]

53. Bakker, E.S.; Van Donk, E.; Immers, A.K. Lake restoration by in-lake iron addition: A synopsis of iron impact on aquatic organisms and shallow lake ecosystems. Aquat. Ecol. 2016, 50, 121-135. [CrossRef]

54. Hossain, M.B.; Jahiruddin, M.; Loeppert, R.H.; Panaullah, G.M.; Islam, M.R.; Duxbury, J.M. The effects of iron plaque and phosphorus on yield and arsenic accumulation in rice. Plant Soil 2008, 317, 167-176. [CrossRef] 